\title{
KARAKTERISTIK DAN KESENJANGAN SPASIAL PENGGUNA INTERNET, E-COMMERCE, SERTA E-BANKING DI JAWA TIMUR
}

\author{
Muhammad Abrar ${ }^{1}$, Rossanto Dwi Handoyo² \\ 1,2Fakultas Ekonomi dan Bisnis, Jurusan Ilmu Ekonomi, Universitas Airlangga \\ Jl. Airlangga No. 4, Gubeng, Surabaya, Jawa Timur, 60286, Indonesia \\ No. Telp./HP: ${ }^{1} 081321628696,{ }^{2} 081553363876$ \\ E-mail: ${ }^{1}$ abrar_tn@bps.go.id, ${ }^{2}$ rossanto_dh@feb.unair.ac.id
}

Naskah diterima pada tanggal 25 Oktober 2019, direvisi tanggal 21 Februari 2020, disetujui tanggal 25 Februari 2020

\section{CHARACTERISTICS AND SPATIAL INEQUALITY OF INTERNET, E-COMMERCE, AND E-BANKING USERS IN EAST JAVA}

\begin{abstract}
The spatial disparity has become one of the biggest challenges in developing countries. However, relatively few studies have examined the mechanism of spatial inequality that explains digital inequality. Amid many closed retail businesses and sluggish public purchasing power issues, e-commerce businesses can survive. Therefore, there is a need for research on the socioeconomic characteristics which form the individual's decision to adopt of internet, ecommerce, and e-banking from the household side as one of the economic actors. In this study, descriptive analysis and logistic regression methods were used with the primary data from the National Socio-Economic Survey (SUSENAS) in 2017. Besides that, Potensi Desa (PODES) and HDI data, Gini Index and percentage of poverty are also used in this study. The results of this study using logistic regression show that individuals who have greater opportunities to become the internet, e-commerce, and e-banking users have the characteristics of young age, college graduates, owning a cellphone, using a computer, working, per capita expenditure, and living in urban areas and having adequate infrastructure telecommunications.
\end{abstract}

Keywords: characteristics, spatial inequality, internet, e-commerce, e-banking.

\begin{abstract}
Abstrak. Kesenjangan spasial telah menjadi salah satu tantangan terbesar di negara-negara berkembang. Namun, relatif sedikit penelitian yang meneliti mekanisme ketimpangan spasial yang menjelaskan kesenjangan digital. Di tengah banyaknya usaha ritel yang tutup dan isu daya beli masyarakat yang lesu, usaha e-commerce mampu bertahan. Oleh karena itu, perlu adanya penelitian mengenai karakteristik sosial ekonomi yang membentuk keputusan individu untuk mengadopsi internet, e-commerce, dan e-banking dari sisi rumah tangga sebagai salah satu pelaku perekonomian. Dalam penelitian ini digunakan metode analisis deskriptif dan regresi logistik dengan data utama dari Survei Sosial Ekonomi Nasional (SUSENAS) tahun 2017. Selain itu, data Potensi Desa (PODES) dan data Indeks Pembangunan Manusia (IPM), Indeks Gini, dan persentase kemiskinan dari Badan Pusat Statistik (BPS) juga digunakan dalam penelitian ini. Hasil penelitian dengan menggunakan regresi logistik menunjukkan bahwa individu yang memiliki peluang lebih besar untuk menjadi pengguna internet, e-commerce, dan e-banking memiliki karakteristik berusia muda, lulusan perguruan tinggi, memiliki ponsel, menggunakan komputer, bekerja, pengeluaran perkapita tinggi, serta tinggal di daerah perkotaan dan memiliki infrastruktur telekomunikasi yang memadai.
\end{abstract}

Kata kunci: karakteristik, kesenjangan spasial, internet, e-commerce, e-banking. 


\section{PENDAHULUAN}

Pesatnya perkembangan teknologi informasi dan komunikasi (TIK) menciptakan sebuah ruang virtual yang membentang di permukaan bumi. Kemajuan dunia internet akhir-akhir ini memicu berkembangnya teknologi baru yang memanfaatkan teknologi jaringan tersebut sebagai media untuk mewujudkan impian manusia dalam memenuhi kebutuhan primer maupun sekundernya melalui proses transaksi melalui internet. Hal ini menjadi tantangan tersendiri bagi perekonomian di Indonesia, khususnya Jawa Timur. Indonesia sebagai negara berkembang memiliki beberapa bukti yang menunjukkan pesatnya perkembangan dunia digital. Berdasarkan laporan APJII (Asosiasi Penyelenggara Jasa Internet Indonesia) sepanjang tahun 2017, sekitar 143 juta orang telah terhubung dengan jaringan internet. Angka-angka di atas sejalan dengan pertumbuhan penetrasi digital di dunia. Namun, meskipun tingkat penetrasi TIK yang tinggi di Indonesia, kesenjangan digital antar provinsi masih terlihat. Berdasarkan data BPS (Badan Pusat Statistik) tahun 2016, persentase individu pengguna internet di Jawa Timur berada di peringkat ke-14 dari 34 provinsi di Indonesia. Proporsi individu yang menggunakan internet di Jawa Timur pada tahun 2016 sebesar 24,12 persen (Badan Pusat Statistik, 2017b). Angka ini masih di bawah dari rata-rata pengguna internet di Indonesia pada tahun 2016 yaitu 25,37 persen. Untuk pegguna internet di Pulau Jawa, posisi terendah adalah Provinsi Jawa Tengah tepat berada di bawah Jawa Timur pada peringkat 15 dengan proporsi sebesar 23,82 persen. Provinsi Papua masih menjadi provinsi dengan tingkat penetrasi internet terendah di Indonesia, yaitu 11,62 persen.

Seiring dengan berkembangnya akses internet, e-commerce (jual beli dengan sistem online) di Indonesia juga tumbuh signifikan. Berdasarkan hasil Sensus Ekonomi (SE) 2016 yang dilakukan BPS, jumlah usaha ecommerce mencapai angka 26,2 juta, naik 17 persen dibandingkan hasil SE 2006 (Badan Pusat Statistik, 2017a). Sementara itu, jumlah nasabah pengguna perbankan elektronik (e-banking) meningkat dari 13,6 juta nasabah pada tahun 2012 menjadi 50,4 juta pada tahun 2016 (Otoritas Jasa Keuangan, 2017). Jika dilihat dari sisi frekuensi transaksi, nilainya meningkat dari 150,8 juta pada tahun 2012 menjadi 405,4 juta pada tahun 2016. Hal ini dapat menjelaskan keterkaitan antara e-commerce, dan e-banking. E-banking dianggap sebagai fasilitator pembayaran yang dihasilkan oleh e-commerce. Oleh karena itu, dengan bantuan e-banking, dapat mempermudah transaksi pada e-commerce. Akan sulit melakukan pembayaran yang berasal dari e-commerce tanpa adanya e-banking.

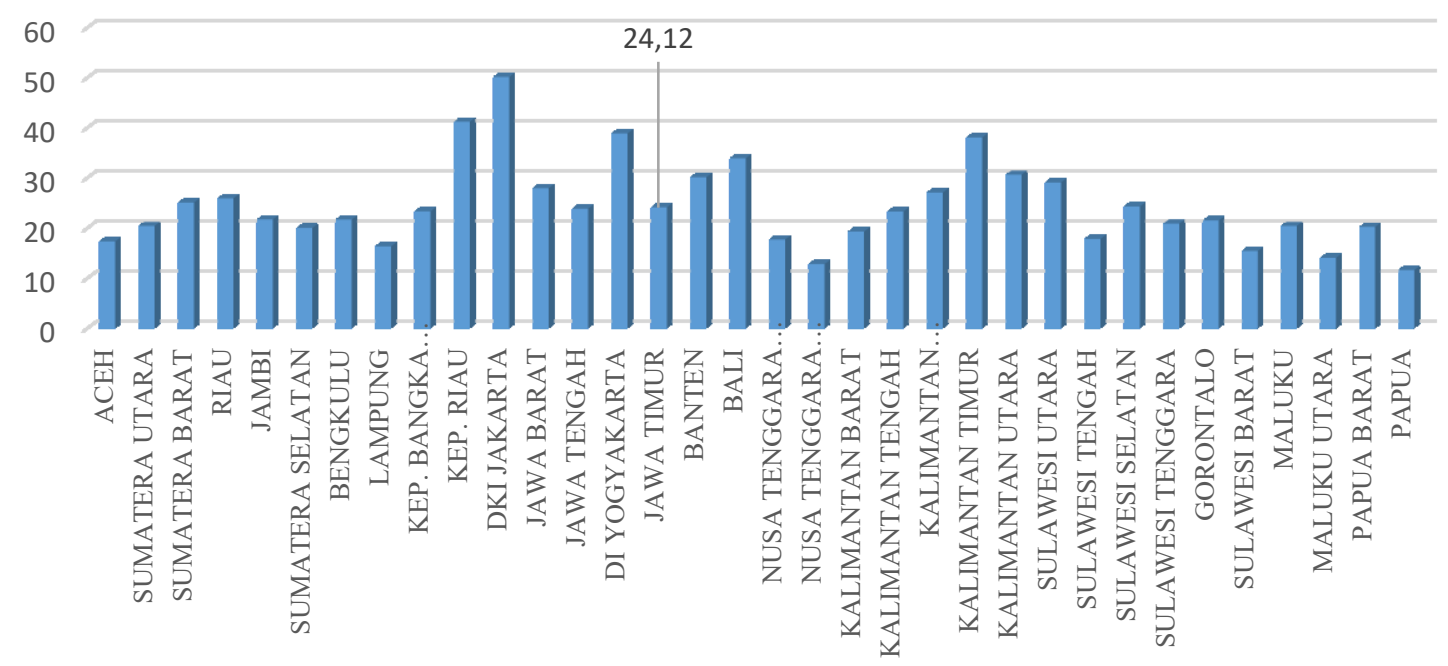

Sumber: BPS, (2016)

Gambar 1. Persentase Individu Pengguna Internet Menurut Provinsi Tahun 2016. 
Jumlah e-commerce dan transaksi $e$ banking yang terus meningkat drastis dari tahun ke tahun menunjukkan bahwa bisnis online akan terus berkembang dan diperkirakan tren positif tersebut akan terus berlanjut ke depannya (Badan Pusat Statistik, 2017b). Kondisi perekonomian saat ini dan gaya hidup era internet dan sosial media membuat banyak pebisnis yang mulai melirik dan bahkan beralih ke bisnis online. Pada era digital saat ini, para pelaku e-commerce dituntut melakukan perubahan untuk meningkatkan daya saingnya. Penggunaan teknologi informasi (TI) dengan memanfaatkan fasilitas internet merupakan salah satu faktor penting yang akan menentukan daya saing. Teknologi yang dibutuhkan oleh pelaku e-commerce tidak saja yang berhubungan dengan produksi atau pemberian jasa, tetapi juga dalam operasional usaha sehari-hari seperti e-banking.

Maraknya bisnis usaha dengan sistem online di Jawa Timur akhir-akhir ini tidak terlepas dari perubahan pola belanja masyarakat dari berbelanja secara konvensional beralih menjadi berbelanja secara online (Badan Pusat Statistik Provinsi Jawa Timur, 2017). Hal ini terjadi karena sebagian masyarakat terutama di daerah perkotaan mengalami keterbatasan waktu untuk berbelanja di toko-toko, ditambah biaya yang cenderung mahal jika dihitung dengan biaya perjalanan. Kondisi perkotaan yang mulai macet juga membuat orang semakin kurang berminat pergi ke toko untuk berbelanja. Banyak pilihan karena bisa mengakses beberapa toko online secara bersamaan, kecepatan akses serta dapat diakses 24 jam juga menjadi penyebab masyarakat beralih berbelanja online. Selain itu juga dikarenakan kian murahnya gadget di pasaran dan besarnya jumlah penduduk usia muda yang melek teknologi di Provinsi Jawa Timur.

Namun demikian, di sisi lain teknologi menimbulkan kerugian kepada sebagian orang yang belum melek teknologi (International Labor Organization, 2017). Contohnya bagaimana bisnis transportasi online perlahan menggerus keuntungan ekonomi dari transportasi konvensional. Fenomena kemajuan teknologi serta derasnya arus digitalisasi yang membuat bisnis berbasis online kian tumbuh subur di Indonesia, juga berdampak negatif pada usaha ritel dan toko konvensional. Semua pihak juga harus menyesuaikan dengan perkembangan teknologi jika tidak, akan ketinggalan. Tetapi pemerintah, sebagai pemangku kebijakan tentunya harus membangun keseimbangan. Jangan sampai teknologi berubah ke arah yang lebih baik, tetapi kemudian merugikan masyarakat yang belum melek teknologi.

Menurut laporan (Badan Pusat Statistik Provinsi Jawa Timur, 2017), pertumbuhan ekonomi Jawa Timur pada tahun 2017 tampaknya berada pada posisi yang baik dengan pertumbuhan tahunan rata-rata $4-6$ persen sejak tahun 2002. Persentase penduduk miskin menurun tajam dari 24,20 persen pada tahun 1998 menjadi 10,64 persen pada tahun 2017. Indeks Pembangunan Manusia juga meningkat tajam dari 61,8 pada 1999 menjadi 70,27 pada 2017. Pembangunan sosial-ekonomi Jawa Timur telah ditandai oleh kesenjangan spasial yang mendalam terlepas dari pertumbuhan ekonominya yang mengesankan. Indeks Gini meningkat dari 0,35 pada 2008 menjadi 0,40 poin pada 2017. Ketimpangan lebih besar terjadi di daerah perkotaan, sementara ketidaksetaraan pendapatan di perdesaan secara konsisten lebih rendah daripada ketidaksetaraan perkotaan. Kesenjangan digital ini merupakan tantangan besar bagi negara berkembang karena perbedaan yang besar menghambat pembangunan ekonomi dan sosial serta tujuan kebijakan publik. Diperlukan kebijakan publik untuk meningkatkan modal sosial dan peluang yang setara.

Berdasarkan latar belakang tersebut, rumusan masalah dalam penelitian ini adalah bagaimana karakteristik pengguna internet, $e$ commerce, dan e-banking, serta kesenjangannya yang terjadi antardaerah di Provinsi Jawa Timur. Selain itu juga faktorfaktor apa saja yang membentuk keputusan individu untuk mengadopsi ketiga layanan tersebut sehingga dapat memberi gambaran kebijakan apa yang perlu dilakukan oleh pemerintah daerah dan masyarakat Jawa Timur dalam rangka menghadapi revolusi 
industri 4.0. Dengan adanya bukti empiris yang menguatkan keberadaan kesenjangan digital yang terukur dan multidimensi, maka diperlukan penelitian yang bertujuan untuk mengidentifikasi kesenjangan spasial dan karakteristik yang membentuk keputusan individu untuk mengadopsi internet, $e$ commerce, dan e-banking di Provinsi Jawa Timur.

\section{LANDASAN KONSEP}

Internet (Interconnected Network) menurut BPS (2017c) adalah jaringan komputer publik yang menyediakan akses ke sejumlah komunikasi termasuk world wide web, e-mail, berita, hiburan, dan file data, terlepas dari perangkat yang digunakan (tidak diasumsikan hanya melalui komputer, mungkin juga melalui telepon seluler, tablet, PDA, mesin game, TV digital, dan lain lain). Menurut Turban (2002) e-commerce adalah proses jual beli produk dan informasi melalui internet. Bisnis usaha berbasis online adalah bisnis apapun yang menjual produk berupa barang atau jasa yang dijalankan dengan media internet (Badan Pusat Statistik, 2017a).

Peran dan keuntungan e-commerce bagi pemerintah adalah meningkatkan daya beli dan kesempatan masyarakat untuk mendapatkan produk atau jasa yang lebih terjangkau karena biaya produksi yang rendah. Namun demikian masih adanya tantangan terkait e-commerce, di antaranya masih terbatasnya layanan pembayaran (ebanking) di daerah perdesaan dan masih terbatasnya infrastruktur telekomunikasi di daerah terpencil, serta kendala jangka waktu pengiriman barang terkait sarana logistik. Istilah electronic banking dapat digambarkan dalam berbagai macam cara. Dalam bentuk yang sangat sederhana, dapat berarti penyedia informasi atau jasa oleh bank kepada nasabahnya melalui komputer, televisi, telepon, ataupun telepon seluler (Daniel, 1999).

Beberapa penelitian terdahulu, perkembangan e-commerce sangat dipengaruhi oleh tingkat perkembangan wilayah di mana beberapa faktor yang sangat menentukan perkembangan e- commerce di Indonesia di antaranya adalah sumber daya manusia yang tercermin dari indeks pembangunan manusia (IPM), infrastruktur ketenagalistrikan serta infrastruktur jaringan internet (Widagdo, 2016). Liao \& Tow (2002) melakukan penelitian untuk menganalisis efek awal dan hubungan antara sikap konsumen dan $e$ commerce berbasis internet. Hasilnya menunjukkan bahwa konten produk, keamanan transaksi, harga, kualitas vendor, pendidikan teknologi informasi, dan penggunaan internet secara signifikan memengaruhi keinginan awal warga Singapura untuk melakukan e-commerce. Jadi semakin banyak pengguna internet maka semakin banyak pula warga melakukan $e$ commerce. Begitu juga semakin banyak warga yang teredukasi dengan komputer dan teknologi informasi maka akan bertambah pula jumlah transaksi e-commerce.

Ketidaksetaraan spasial didefinisikan sebagai perbedaan dalam sumber daya dan layanan karena perbedaan dalam faktor sosial dan ekonomi lintas geografi (Kanbur, 2005). Hal ini tidak hanya akan mengubah dunia sosial tetapi juga akan secara efektif menghilangkan jarak sebagai faktor biaya $\mathrm{F}$ (Grimes, 2000). Menurut pandangan ini, ekonomi akan bekerja dalam ruang virtual, biaya transportasi akan berkurang secara drastis, jarak akan menjadi hal yang kurang penting, dan daerah pinggiran akan mendapatkan manfaat yang didasarkan pada industri manufaktur. Lokasi geografis, orangorang yang tinggal di pusat kota memiliki lebih banyak akses pada komputer daripada di daerah perdesaan.

Pengeluaran per kapita digunakan sebagai proksi pendapatan. Hal ini dikarenakan sulitnya memperoleh informasi pendapatan yang tepat pada banyak negara berkembang sehingga menjadi bias, terutama di rumah tangga pertanian subsisten. Pengeluaran per kapita merupakan ukuran sumber daya ekonomi rumah tangga yang lebih akurat, baik di negara berkembang maupun negara maju (Deaton, A., \& Zaidi, 2002; Jorgensen, 2002).

Difusi TIK diperoleh melalui hubungan antara kesenjangan digital dan pelebaran ketimpangan spasial dalam negara 
berkembang. Peningkatan penggunaan internet juga berpotensi untuk memperburuk kesenjangan spasial yang ada di negara transisi dan berkembang (Norris, 2001). Konsekuensi dari munculnya TIK adalah kesenjangan digital geo-spasial (Rallet, A., \& Rochelandet, 2007).

Technology Acceptence Model (TAM) merupakan teori penerimaan teknologi. Davis pada tahun 1989 mengemukakan teori ini dan dikembangkan lagi oleh beberapa peneliti. Theory of Reasoned Action (TRA) dilandasi oleh model TAM. TRA menjelaskan psikologi sosial berkaitan dengan perilaku seseorang yang dilakukan secara sadar (Nor, 2013). Berdasarkan TRA, pengguna suatu sistem ditentukan oleh persepsi dan sikap individu yang pada akhirnya membentuk perilaku seseorang dalam penerimaan suatu teknologi informasi.

Ketimpangan dalam modal manusia meningkatkan akses internet yang tidak merata. Pendidikan adalah salah satu bentuk pembangunan sosial yang paling signifikan, menghasilkan keterampilan dan pengalaman yang berkontribusi pada penggunaan TIK. Lembaga akademis juga dapat memainkan peran penting dalam menyebarkan TIK. Distribusi dan akses yang tidak merata pada pendidikan dapat menyebabkan kesenjangan digital. Wilson, Wallin \& Reiser (2003) menjelaskan bahwa jumlah pengguna internet sangat dipengaruhi oleh akses internet di sekolah, pusat komunitas, dan warnet, terutama di negara-negara miskin di mana akses komputer di rumah sangat terbatas.

Kesenjangan dalam distribusi infrastruktur telekomunikasi menghasilkan kesenjangan digital (Purba Rao, 2018; Mariscal, 2005). Setiap individu memerlukan akses pada ponsel, komputer, dan jaringan untuk mengakses internet. Jaringan telepon dan fasilitas satelit tidak dapat digunakan seluas mungkin seperti di negara maju. Di Indonesia, layanan telekomunikasi dasar masih tidak tersedia untuk beberapa pulau terpencil. Akses yang tidak merata pada infrastruktur dan layanan telekomunikasi merupakan salah satu tantangan untuk menjembatani kesenjangan digital dan memulihkannya harus menjadi tujuan semua pemangku kepentingan di Indonesia.

\section{METODE PENELITIAN}

Analisis deskriptif dan regresi logistik adalah metode yang digunakan dalam penelitian ini. Dalam penelitian ini analisis deskriptif dalam bentuk tabel dan grafik untuk variabel-variabel sosial demografi yang berkaitan dengan pengakses internet dan pelaku e-commerce serta e-banking. Probabilitas untuk terjadinya suatu peristiwa dimodelkan menggunakan fungsi logistik. Regresi logistik memungkinkan memprediksi probabilitas adopsi suatu layanan (internet, $e$ commerce, dan e-banking) dengan bantuan sejumlah variabel independen, karakteristik sosial-ekonomi individu. Model ini telah digunakan oleh Serener (2016) dan Fonseca (2014).

Penelitian ini menggunakan data mikro dari Survei Sosial Ekonomi Nasional (SUSENAS) yang dilakukan BPS pada Maret 2017. Cakupan survei ini meliputi 300.000 rumah tangga sampel yang tersebar di 34 provinsi dan 542 kabupaten/kota di Indonesia. Di Jawa Timur jumlah sampel SUSENAS sebesar 29.960 rumah tangga yang terdiri dari 88.337 individu yang tersebar di 38 kabupaten/kota. Sampel dipilih dengan metode two stage one phase stratified sampling (Badan Pusat Statistik, 2017b). Data SUSENAS dikumpulkan melalui wawancara langsung dengan menggunakan kuesioner. Unit observasi penelitian adalah penduduk berusia 10 tahun ke atas yang mengakses internet, e-commerce, dan e-banking dalam tiga bulan terakhir. Hanya pada batas usia ini pertanyaan mengenai teknologi ditanyakan serta terkait dengan pekerjaaannya. Data yang dihasilkan dapat mengestimasi angka hingga tingkat kabupaten/kota.

Selain itu data Potensi Desa (PODES) dari BPS juga digunakan sebagai data pendukung yang memberikan informasi tentang distribusi infrastruktur telekomunikasi seperti sinyal jaringan telepon dan jumlah universitas. Data IPM, Indeks Gini, dan persentase kemiskinan yang bersumber dari publikasi BPS juga digunakan dalam penelitian ini. Kumpulan data ini sesuai untuk tujuan dan hipotesis penelitian ini karena memberikan informasi tentang penggunaan internet, e-commerce, dan $e$ - 
banking yang dipertimbangkan bersama variabel terkait lainnya. Untuk keperluan analisis, karakteristik responden diubah menjadi nilai-nilai biner, yang mengindikasikan keanggotaan seorang individu ke salah satu nilai kategori. Ini dilakukan dengan tujuan untuk menghitung estimasi odds ratio dan marginal effect. Kategori dengan nilai estimasi lebih besar dari 1 menunjukkan peluang lebih tinggi daripada kelompok referensi. Di sisi lain, kategori dengan nilai estimasi di bawah 1 menunjukkan peluang yang lebih rendah daripada kelompok referensi.

Kesenjangan internet, e-commerce, dan e-banking diukur dengan variabel dummy yang menunjukkan akses individu ke layanan. Kesenjangan pengguna dalam karakteristik sosial-demografi individu yang memiliki atau tidak memiliki akses intenet, e-commerce, dan e-banking. Perbedaan akses ketiga layanan terkait dengan karakteristik individu, termasuk usia, jenis kelamin, pekerjaan, tingkat pendidikan, dan pendapatan (van Dijk, 2012). Persamaan regresi model sebagai berikut, dengan mempertimbangkan seorang individu $\mathrm{i}$ yang bertempat tinggal di kabupaten/kota j, modelnya adalah:

$$
E i j^{*}=\beta o+\beta i j X i j+\sum \beta \mathrm{jWj}+\varepsilon i j+\mu \mathrm{j}
$$

Dengan Eij* $=\operatorname{logit}\left(\mathrm{P}\left(\mathrm{Eij}^{*}=1\right)\right), \mathrm{Xij}$ adalah seperangkat karakteristik individu dan $\mathrm{Wj}$ adalah seperangkat karakteristik kabupaten.

Beberapa langkah digunakan untuk menganalisis data (Gujarati, 2009). Pertama, untuk mengidentifikasi akses digital internet, e-commerce, dan e-banking digunakan lintas karakteristik sosial-ekonomi, dan demografi (yaitu jenis kelamin, status perkawinan, kedudukan dalam rumah tangga, usia, status pekerjaan, dan pengeluaran per kapita). Usia dibagi menjadi enam kategori, tingkat pendidikan dibagi menjadi empat kategori serta status pekerjaan dibagi menjadi bekerja dan tidak bekerja. Selain itu juga ditambahkan variabel individu sebagai peserta aktif BPJS non Penerima Bantuan uran (PBI) dalam penelitian ini karena ingin melihat keterkaitan pembayaran iuran BPJS terkait dengan fasilitas e-banking.
Variabel kontrol termasuk variabel individu dan kabupaten yang terkait dengan kesenjangan internet. Studi sebelumnya mengidentifikasi bahwa akses internet telah dikaitkan dengan sejumlah karakteristik demografi dan sosial ekonomi individu (Norris, 2001; Wilson, Wallin \& Reiser, 2003; Mossberger, K., Tolbert, J., \& Stansbury, 2003). Usia, pendapatan, pendidikan, jenis kelamin, dan lokasi geografis perkotaan-perdesaan juga terkait pada kesenjangan digital (Wilson, Wallin \& Reiser, 2003; Warschauer, 2003; Mossberger, K., Tolbert, J., \& Stansbury, 2003). Tingkat pendapatan dan pencapaian pendidikan diidentifikasi sebagai menyediakan variabel penjelas paling kuat untuk akses media digital (Quibria, Ahmed \& Tschang, 2003; Hilbert, 2013). Variabel bebas dan variabel terikat yang digunakan dalam penelitian ini, Tabel 1.

Kedua, ekonomi, modal manusia, infrastruktur telekomunikasi, dan layanan pendidikan merupakan empat ukuran ketimpangan spasial yang digunakan dalam penelitian ini, yaitu: Pertama, Indeks Gini adalah ukuran standar ketidaksetaraan spasial modal ekonomi (Kanbur, 2005). Penelitian sebelumnya menunjukkan bahwa Indeks Gini yang lebih tinggi terkait dengan kesenjangan digital (Kiiski \& Pohjola, 2002). Kedua, untuk memeriksa apakah ketimpangan spasial dalam modal manusia berhubungan dengan kesenjangan digital, kesenjangan kabupaten dalam tingkat pendidikan, dan IPM digunakan sebagai proksi untuk kesenjangan spasial dalam modal manusia. Kanbur \& Venables (2005) juga telah menggunakan ukuran ini pada penelitiannya. Ketiga, ketimpangan spasial dalam infrastruktur telekomunikasi diukur oleh kesenjangan kabupaten dalam ketersediaan infrastruktur telekomunikasi seperti kepemilikan ponsel, penggunaan komputer, dan jaringan sinyal ponsel. Studi sebelumnya menunjukkan bahwa akses internet antara dan di dalam negara terkait dengan ketersediaan infrastruktur telekomunikasi ini (Norris, 2001; Quibria, Ahmed \& Tschang, 2003). Keempat, ketimpangan spasial dalam layanan pendidikan diukur dengan kesenjangan kabupaten dalam fasilitas pendidikan tinggi (perguruan tinggi dan universitas). 


\section{Tabel 1}

Pengukuran Variabel yang Digunakan

\begin{tabular}{lll}
\hline Nama Variabel & \multicolumn{1}{c}{ Keterangan } & Sumber \\
\hline $\begin{array}{lll}\text { Variabel Dependen } \\
\text { Internet }\end{array}$ & $\begin{array}{l}\text { 1 jika individu menggunakan internet untuk keperluan pribadi dalam 3 } \\
\text { bulan terakhir; 0 sebaliknya. }\end{array}$ & SUSENAS 2017 \\
E-commerce & 1 jika individu menggunakan internet untuk membeli atau memesan & SUSENAS 2017 \\
& barang atau jasa untuk penggunaan pribadi dalam 3 bulan terakhir; 0 & (R.707E dan \\
& sebaliknya. & R.707F) \\
E-banking & 1 jika individu menggunakan internet untuk perbankan dalam 3 bulan & SUSENAS 2017 \\
& terakhir; 0 sebaliknya. & (R.707H)
\end{tabular}

Variabel Independen

Jenis Kelamin

1 jika laki-laki; 0 jika perempuan.

\section{Karakteristik Individu/Rumah Tangga Karakteristik Individu}

Status Perkawinan 1 belum menikah; 0 sudah menikah.

Kedudukan dalam 1 kepala rumah tangga (krt); 0 anggota rumah tangga (art)

Rumah Tangga

Usia

Pendidikan

Kepemilikan Ponsel

Penggunaan

Komputer

Pekerjaan

BPJS

Tempat Tinggal

Pengeluaran per kapita

\section{IPM}

Indeks Gini

Kemiskinan

Rasio Sinyal Ponsel

Rasio Fasilitas Pendidikan
Dikelompokkan dalam lima kelompok usia $(10-19 ; 20-29 ; 30-39 ; 40-$ 49; $\geq 50)$.

Pendidikan dikelompokkan dalam empat kategori (SD dan yang belum/tidak bersekolah; SMP sederajat; SMA sederajat; Perguruan Tinggi).

1 jika memiliki; 0 jika tidak memiliki.

1 jika menggunakan; 0 jika tidak menggunakan.

Status Pekerjaan. 1 jika bekerja; 0 jika tidak bekerja.

Kepesertaan dalam Badan Penyelenggara Jaminan Sosial BPJS Non PBI. 1 jika individu merupakan pesesta BPJS; 0 jika bukan peserta BPJS

Lokasi tempat tinggal. 1 jika di perkotaan, 0 jika pedesaan.

Pengeluaran rumah tangga per kapita dalam sebulan (juta rupiah)

Indeks Pembangunan Manusia

Gini Rasio

Persentase kemiskinan

Kesenjangan dalam Infrastruktur Telekomunikasi

Rasio sinyal telepon seluler/handphone.

Kesenjangan dalam Infrastruktur Pendidikan

Rasio jumlah universitas.

\section{Karakteristik Rumah Tangga}

\section{Karakteristik Kabupaten/Kota}

SUSENAS 2017

(R405)

SUSENAS 2017

(R404)

SUSENAS 2017

(R403)

SUSENAS 2017

(R407)

SUSENAS 2017

(R517)

SUSENAS 2017

(R702)

SUSENAS 2017

(R703)

SUSENAS 2017

(R801a)

SUSENAS 2017

(R901b)

SUSENAS 2017

(R105)

SUSENAS

2017.KP (R.277)

BPS 2017

BPS 2017

BPS 2017

PODES 2014

(R1005b)

PODES 2014

(R701f)

Sumber: Penelitian

Studi sebelumnya menunjukkan bahwa kehadiran perguruan tinggi dan universitas merupakan dukungan penting untuk penetrasi internet (Norris, 2001; Wilson, Wallin \& Reiser, 2003; Mossberger, K., Tolbert, J., \& Stansbury, 2003).

\section{HASIL PENELITIAN DAN PEMBAHASAN}

Pada era digital, untuk mengetahui seberapa jauh perkembangan kesejahteraan rakyat dapat dilihat dari kepemilikan/penguasaan akses teknologi 
informasi dan komunikasi. Hasil SUSENAS, dari tahun ke tahun menunjukkan terjadinya peningkatan pada jumlah individu yang mengakses internet. Pada tahun 2015, 20,66 persen penduduk Jawa Timur pernah mengakses internet selama tiga bulan yang lalu (periode referensi survei), meningkat pada tahun 2016, 24,12 persen dan terus meningkat menjadi 32,90 persen pada tahun 2017 (Badan Pusat Statistik, 2017b). Sedangkan pengguna e-commerce dan $e$ banking di Jawa Timur pada tahun 2017 sebesar 5,92 persen dan 1,85 persen. Jika dilihat dari jenis kelaminnya, penduduk Jawa Timur yang mengakses internet dan $e$ banking lebih banyak laki-laki. Jika dilihat berdasarkan jenis kelaminnya sebagian besar pelaku belanja online di Jawa Timur adalah wanita. Hal ini sangat menarik karena untuk pengakses internet dan e-banking lebih dominan berjenis kelamin laki-laki namun untuk pelaku belanja online lebih dominan perempuan. Hal ini sejalan dengan survei yang dilakukan APJII (2017) bahwa jenis produk yang paling dominan dibeli secara online yaitu busana sebesar 71,6 persen dan kosmetik sebesar 20 persen.

Untuk status perkawinan, pengguna internet masih didominasi oleh penduduk yang belum menikah sebesar 52,19 persen. Sedangkan untuk pengguna e-commerce dan e-banking didominasi oleh penduduk yang sudah menikah sebesar 59,92 persen dan 73,81 persen. Hal ini ada hubungannya dengan tingkat finansial, penduduk yang sudah menikah memiliki tanggung jawab secara materi terhadap keluarganya dalam memenuhi kebutuhan sehari-hari. Sedangkan menurut kedudukannya di dalam rumah tangga, anggota rumah tangga lebih banyak menggunakan internet, e-commerce, dan e-banking daripada kepala keluarga.

Keberadaan internet pada saat ini bukanlah hal yang asing lagi, mulai dari anak-anak hingga orang tua sebagian besar telah mengenalnya. Pengguna internet masih didominasi oleh generasi milenial yaitu berusia 10 - 19 tahun 32,27 persen dari total pengguna internet di Jawa Timur. Hal ini sesuai dengan data dari Asosiasi Penyelenggara Jasa Internet (2017), mayoritas pengguna memanfaatkan internet untuk komunikasi, media sosial, dan mencari pekerjaan. Sedangkan untuk pengguna e-commerce didominasi pada usia 20 - 29 tahun sebesar 36,18 persen. Pada usia ini mayoritas pelaku e-commerce sudah memiliki pekerjaan sehingga dapat membelanjakan barang dan jasa dari hasil pendapatannya. Berbeda halnya dengan pengguna $e$-banking, mayoritas berada pada usia 30-39 tahun sebesar 30,42 persen. Hal ini terjadi karena pada usia tersebut biasanya pengguna sudah mencapai level mapan dan pengguna $e$-banking masih melek teknologi.

Berdasarkan pendidikan tertinggi, pengguna internet dan e-commerce didominasi oleh penduduk dengan pendidikan tertinggi SMA/setara yaitu 37,18 persen dan 45,19 persen dari total pengguna masing-masing layanan. Sedangkan pengguna e-banking didominasi oleh penduduk dengan pendidikan tertinggi perguruan tinggi sebesar 47,18 persen. Tingginya lulusan perguruan tinggi yang menggunakaan e-banking dikarenakan adanya kepercayaan yang lebih tinggi terhadap akses perbankan dan lebih memahami kemudahan yang didapatkan dari memanfaatkan layaaan tersebut. Hal ini didapatkan seiring bertambahnya pendidikan dan pengalaman seseorang. Kepemilikan ponsel (telepon seluler) sangat dominan bagi pengguna internet, e-commerce, dan $e$ banking yaitu sebesar 95,98 persen, 98,81 persen, dan 99,57 persen. Hal ini dikarenakan mayoritas penduduk menggunakan perangkat ponsel sebagai alat bantu dalam menggunakan ketiga layanan tersebut. Selain itu juga penggunaan komputer juga dominan bagi pengguna internet, e-commerce, dan e-banking yaitu sebesar 55,54 persen, 66,14 persen, dan 81,94 persen.

Berdasarkan aktivitas utama pengguna internet, e-commerce, dan e-banking di Jawa Timur didominasi oleh penduduk dengan aktivitas utama bekerja yaitu sebesar 54,22 persen, 69,05 persen, dan 80,11 persen. Dengan pendapatan yang didapatkan, penduduk yang bekerja dapat dengan leluasa menggunakan ketiga layanan tersebut. Berdasarkan pengeluaran per kapita, pengguna pada ketiga layanan tersebut di 
Jawa Timur didominasi oleh penduduk dengan pengeluaran per kapita per bulan yang cukup besar dengan rata-rata 1,3 juta untuk internet, 1,7 juta untuk e-commerce dan 2,5 juta untuk e-banking. Jika pengeluaran per kapita dijadikan sebagai pendekatan pendapatan maka dapat dikatakan bahwa pengguna ketiga layanan adalah penduduk dengan pendapatan tinggi. Semakin tinggi pengeluaran bulanan, semakin tinggi tingkat penggunaan. Ini berlaku untuk semua layanan. Hasil ini berguna untuk menentukan kebijakan yang dapat menjembatani kesenjangan digital. Jika dilihat dari persebarannya, penduduk yang mengakses internet mayoritas adalah penduduk perkotaan sebesar 68,37 persen sedangkan 31,63 persen adalah penduduk yang tinggal di perdesaan.

Tabel 2

Karakteristik Sampel

\begin{tabular}{|c|c|c|c|}
\hline & Internet & E-commerce & E-banking \\
\hline \multirow[t]{2}{*}{ Karakteristik Individu /Rumah Tangga } & $\%$ atau & $\%$ atau Mean & $\%$ atau \\
\hline & Mean \pm SD & $\pm \mathrm{SD}$ & Mean $\pm \mathrm{SD}$ \\
\hline Pengguna & $32.90 \%$ & $5.92 \%$ & $1.85 \%$ \\
\hline \multicolumn{4}{|l|}{ Jenis Kelamin } \\
\hline Pria & 53.71 & 48.44 & 54.35 \\
\hline Wanita & 46.29 & 51.56 & 45.65 \\
\hline \multicolumn{4}{|l|}{ Status Perkawinan } \\
\hline Belum Menikah & 52.19 & 40.08 & 26.19 \\
\hline Sudah Menikah & 47.81 & 59.92 & 73.81 \\
\hline \multicolumn{4}{|l|}{ Kedudukan dalam rumah tangga } \\
\hline Kepala rumah tangga & 19.64 & 26.36 & 40.45 \\
\hline Anggota Rumah Tangga & 80.36 & 73.64 & 59.55 \\
\hline \multicolumn{4}{|l|}{ Usia } \\
\hline $10-19$ & 32.27 & 15.99 & 7.34 \\
\hline $20-29$ & 29.65 & 36.18 & 26.13 \\
\hline $30-39$ & 20.31 & 26.92 & 30.42 \\
\hline $40-49$ & 11.22 & 14.23 & 19.34 \\
\hline$>=50$ & 6.55 & 6.68 & 16.77 \\
\hline \multicolumn{4}{|l|}{ Pendidikan } \\
\hline SD Sederajat/Tidak Bersekolah & 23.35 & 11.65 & 10.53 \\
\hline SMP Sederajat & 23.16 & 15.59 & 7.28 \\
\hline SMA Sederajat & 37.18 & 45.19 & 35.01 \\
\hline Perguruan Tinggi & 16.31 & 27.57 & 47.18 \\
\hline \multicolumn{4}{|l|}{ Kepemilikan Ponsel } \\
\hline Ya & 95.98 & 98.81 & 99.57 \\
\hline Tidak & 4.02 & 1.19 & 0.43 \\
\hline \multicolumn{4}{|l|}{ Penggunaan Komputer } \\
\hline $\mathrm{Ya}$ & 55.54 & 66.14 & 81.94 \\
\hline Tidak & 44.46 & 33.86 & 18.06 \\
\hline \multicolumn{4}{|l|}{ Bekerja } \\
\hline $\mathrm{Ya}$ & 54.22 & 69.05 & 80.11 \\
\hline Tidak & 45.78 & 30.95 & 19.89 \\
\hline \multicolumn{4}{|l|}{ BPJS Non PBI } \\
\hline $\mathrm{Ya}$ & 20.82 & 25.90 & 35.13 \\
\hline Tidak & 79.18 & 74.10 & 64.87 \\
\hline \multicolumn{4}{|l|}{ Tempat Tinggal } \\
\hline Perkotaan & 68.37 & 78.55 & 84.39 \\
\hline Pedesaan & 31.63 & 21.45 & 15.61 \\
\hline $\begin{array}{c}\text { Pengeluaran per kapita (dalam jutaan rupiah) } \\
\text { Karakteristik Kabupaten }\end{array}$ & $1.328 \pm 1.271$ & $1.725 \pm 1.605$ & $2.495 \pm 2.156$ \\
\hline Indeks Gini & $0.34 \pm 0.03$ & $0.35 \pm 0.03$ & $0.36 \pm 0.03$ \\
\hline IPM & $71.87 \pm 5.44$ & $73.22 \pm 5.42$ & $74.39 \pm 5.64$ \\
\hline Persentase Kemiskinan & $10.51 \pm 4.39$ & $9.51 \pm 4.16$ & $8.85 \pm 4.06$ \\
\hline Rasio Sinyal Ponsel & $0.99 \pm 0.01$ & $0.99 \pm 0.01$ & $0.99 \pm 0.01$ \\
\hline Jumlah Universitas & $12.17 \pm 9.79$ & $13.22 \pm 10.73$ & $15.93 \pm 12.89$ \\
\hline
\end{tabular}


Sejalan dengan penggunaan internet, pelaku e-commerce dan e-banking mayoritas berada di wilayah perkotaan. Dari seluruh penduduk yang pernah melakukan $e$ commerce 78,55 persen ada di wilayah perkotaan dan 21,45 persen ada di wilayah perdesaan. Sedangkan pengguna e-banking lebih tinggi, yaitu di perkotaan sebesar 84,39 persen dan hanya 15,61 persen di perdesaan. Sedangkan untuk karakteristik kabupaten, rata-rata Indeks Gini sebesar 0,34 - 0,36. IPM berkisar antara 71,87 - 74,39 dan persentase kemiskinan berkisar 8,85 - 10,51. Rasio sinyal ponsel 0,99 dan 12 - 15 untuk rata-rata jumlah universitas pada masingmasing layanan.

Untuk analisis spasial, pada Tabel 3 menunjukkan kabupaten/kota di Jawa Timur yang mempunyai persentase pengguna internet, e-commerce, dan e-banking tertinggi dan terendah tahun 2017. Kota Malang merupakan kota dengan penduduk yang mengakses internet tertinggi diikuti dengan Surabaya dan Madiun. Sedangkan tiga kabupaten dengan persentase pengakses internet terendah adalah Pamekasan, Sumenep dan Sampang. Untuk pengakses $e-$ commerce tertinggi diduduki oleh Kota Malang diikuti dengan Madiun dan Batu. Sedangkan kabupaten dengan persentase pengakses e-commerce terendah adalah Probolinggo, Sampang, dan Bangkalan. Untuk pengakses e-banking, Kota Surabaya merupakan kota dengan penduduk pengakses tertinggi diikuti dengan Malang dan Madiun. Sedangkan kabupaten dengan persentase pengakses e-banking terendah adalah Pasuruan, Sampang, dan Bangkalan. Dapat disimpulkan bahwa penetrasi ketiga layanan masih terpusat di kota-kota besar di Jawa Timur (Malang, Madiun, Batu, dan Surabaya). Sedangkan penetrasi terendah masih didominasi oleh kabupaten yang berada di Pulau Madura (Pamekasan, Sumenep, Bangkalan, dan Sampang).

Hasil odds ratio untuk tiga model sebagai berikut: jenis kelamin dan status perkawinan memainkan peran penting dalam menjelaskan adopsi ketiga layanan (laki-laki dan belum menikah meningkatkan penggunaan pada internet serta perempuan dan sudah menikah meningkatkan penggunaan pada e-commerce dan $e$ banking). Hasil ini sejalan dengan literatur sebelumnya yang menemukan bahwa jenis kelamin dan status perkawinan memainkan peran penting dalam membuat keputusan untuk menggunakan layanan tertentu atau tidak (Richard et al., 2010; Martín \& Jiménez, 2011). Menjadi kepala rumah tangga meningkatkan peluang pengguna $e$ commerce dan e-banking. Namun anggota rumah tangga lebih berpeluang menjadi pengguna internet. Catatan: kategori referensi adalah perempuan, sudah menikah, anggota rumah tangga, penduduk berusia $>50$ tahun, pendidikan dasar, tidak memiliki ponsel, tidak menggunakan komputer, tidak bekerja, bukan peserta BPJS non PBI, tinggal di perdesaan. Pengaruh usia secara keseluruhan signifikan di kedua layanan (internet dan e-commerce) yang dipertimbangkan (nilai $\mathrm{p}<0,001$ ). Individu yang termasuk dalam kelompok 10 - 19 tahun memiliki peluang terbesar untuk mengadopsi internet dan kelompok 20 - 29 tahun memiliki peluang terbesar untuk mengadopsi e-commerce. Bahkan, peluang mereka untuk mengakses internet dan menjadi pembeli online 22,40 dan 4,88 kali lebih besar daripada kelompok referensi individu usia 50 tahun ke atas. Namun, individu berusia 10 - 19 dan 40 - 49 tahun tidak berbeda secara signifikan dengan kelompok referensi untuk e-banking.

Individu yang termasuk dalam kelompok 30 - 39 tahun memiliki peluang terbesar untuk mengadopsi e-banking yaitu sebesar 1,37 kali lebih besar dari kelompok lebih dari 50 tahun. Juga dalam kasus ini, peluang terendah sesuai dengan kelompok referensi ( $\geq 50$ tahun). Peluang menjadi $e$ commerce meningkat dengan meningkatnya pendidikan pada semua layanan. Penduduk dengan lulusan perguruan tinggi memiliki peluang yang terbesar mengadopsi internet sebesar 13,39 kali lebih besar dari kelompok berpendidikan dasar. 
Tabel 3

Distribusi Spasial Menurut Kabupaten/Kota di Provinsi Jawa Timur

\begin{tabular}{|c|c|c|c|c|c|c|}
\hline \multirow{2}{*}{$\begin{array}{c}\text { No } \\
1\end{array}$} & \multicolumn{2}{|c|}{ \% Internet (Kabupaten/Kota) } & \multicolumn{2}{|c|}{$\%$ E-commerce (Kabupaten/Kota) } & \multicolumn{2}{|c|}{ \% E-banking (Kabupaten/Kota) } \\
\hline & Kota Malang & 59.85 & Kota Malang & 19.22 & Kota Surabaya & 7.66 \\
\hline 2 & Kota Surabaya & 56.17 & Kota Madiun & 15.61 & Kota Malang & 6.99 \\
\hline 3 & Kota Madiun & 55.51 & Kota Batu & 12.34 & Kota Madiun & 5.93 \\
\hline 4 & Sidoarjo & 55.32 & Kota Surabaya & 11.97 & Kota Kediri & 4.70 \\
\hline 5 & Kota Batu & 49.66 & Sidoarjo & 11.40 & Sidoarjo & 3.95 \\
\hline 6 & Kota Mojokerto & 48.34 & Kota Pasuruan & 11.05 & Kota Pasuruan & 3.21 \\
\hline 7 & Kota Kediri & 47.08 & Kota Kediri & 10.88 & Kota Mojokerto & 2.75 \\
\hline 8 & Kota Blitar & 46.67 & Kota Mojokerto & 9.88 & Kota Batu & 2.70 \\
\hline 9 & Kota Pasuruan & 44.01 & Kota Blitar & 9.33 & Kota Probolinggo & 2.49 \\
\hline 10 & Gresik & 43.47 & Gresik & 9.23 & Kota Blitar & 2.40 \\
\hline 11 & Kota Probolinggo & 42.05 & Kota Probolinggo & 8.91 & Gresik & 2.13 \\
\hline 12 & Mojokerto & 38.07 & Magetan & 7.07 & Blitar & 2.00 \\
\hline 13 & Tulungagung & 37.94 & Tulungagung & 6.47 & Trenggalek & 1.95 \\
\hline 14 & Madiun & 35.87 & Mojokerto & 6.39 & Jombang & 1.69 \\
\hline 15 & Ponorogo & 34.89 & Lamongan & 5.64 & Ponorogo & 1.60 \\
\hline 16 & Blitar & 32.47 & Madiun & 5.57 & Magetan & 1.46 \\
\hline 17 & Jombang & 32.27 & Kediri & 5.08 & Mojokerto & 1.42 \\
\hline 18 & Magetan & 31.78 & Ponorogo & 4.84 & Tulungagung & 1.40 \\
\hline 19 & Kediri & 30.82 & Banyuwangi & 4.84 & Situbondo & 1.27 \\
\hline 20 & Lamongan & 30.48 & Blitar & 4.79 & Pamekasan & 1.23 \\
\hline 21 & Malang & 30.37 & Trenggalek & 4.76 & Lamongan & 1.20 \\
\hline 22 & Bojonegoro & 27.96 & Jombang & 4.63 & Madiun & 1.17 \\
\hline 23 & Trenggalek & 27.81 & Malang & 4.25 & Malang & 1.12 \\
\hline 24 & Banyuwangi & 27.62 & Ngawi & 3.91 & Kediri & 1.09 \\
\hline 25 & Nganjuk & 27.30 & Jember & 3.63 & Banyuwangi & 0.98 \\
\hline 26 & Pasuruan & 26.59 & Situbondo & 3.47 & Pacitan & 0.96 \\
\hline 27 & Ngawi & 26.16 & Nganjuk & 3.27 & Bondowoso & 0.93 \\
\hline 28 & Tuban & 25.79 & Bondowoso & 3.23 & Bojonegoro & 0.87 \\
\hline 29 & Pacitan & 24.25 & Lumajang & 2.92 & Ngawi & 0.86 \\
\hline 30 & Situbondo & 23.67 & Bojonegoro & 2.81 & Jember & 0.65 \\
\hline 31 & Bangkalan & 22.37 & Pasuruan & 2.77 & Probolinggo & 0.63 \\
\hline 32 & Jember & 22.28 & Pacitan & 2.73 & Tuban & 0.60 \\
\hline 33 & Lumajang & 20.14 & Tuban & 2.69 & Lumajang & 0.58 \\
\hline 34 & Bondowoso & 19.69 & Pamekasan & 2.66 & Nganjuk & 0.51 \\
\hline 35 & Probolinggo & 18.49 & Sumenep & 2.57 & Sumenep & 0.51 \\
\hline 36 & Pamekasan & 18.22 & Probolinggo & 2.19 & Pasuruan & 0.46 \\
\hline 37 & Sumenep & 18.19 & Sampang & 1.97 & Sampang & 0.41 \\
\hline 38 & Sampang & 16.82 & Bangkalan & 1.57 & Bangkalan & 0.35 \\
\hline
\end{tabular}

Sumber: Hasil Penelitian, (2017)

Begitu juga peluang mengadopsi $e$ commerce juga meningkat seiring dengan meningkatnya pendidikan. Penduduk lulusan perguruan tinggi memiliki peluang terbesar sebesar 3,61 kali lebih besar dari kelompok referensi. Penduduk lulusan perguruan tinggi memiliki peluang menggunakan $e$ banking 3,46 kali lebih tinggi dari berpendidikan dasar. 


\section{Tabel 4}

Estimasi Odds Ratio Regresi Logistik untuk Setiap Layanan di Provinsi Jawa Timur Tahun 2017

\begin{tabular}{|c|c|c|c|c|c|c|c|c|c|}
\hline \multirow{2}{*}{\begin{tabular}{l}
\multicolumn{1}{c}{ Variabel } \\
Karakteristik \\
Individu/ Rumah \\
Tangga
\end{tabular}} & \multicolumn{3}{|c|}{ Internet } & \multicolumn{3}{|c|}{ E-commerce } & \multicolumn{3}{|c|}{ E-banking } \\
\hline & Odds ratio & $\mathrm{Z}$ & $p$ value & Odds ratio & $\mathrm{z}$ & $p$ value & $\begin{array}{l}\text { Odds } \\
\text { ratio }\end{array}$ & $\mathrm{Z}$ & $p$ value \\
\hline Jenis Kelamin & & & $<0.001$ & & & $<0.001$ & & & 0.052 \\
\hline Pria & 1.27 & 7.81 & & 0.72 & -8.65 & & 0.87 & -1.95 & \\
\hline Wanita & 1.00 & & & 1.00 & & & 1.00 & & \\
\hline Status Perkawinan & & & $<0.001$ & & & 0.003 & & & $<0.001$ \\
\hline Belum Menikah & 1.75 & 13.34 & & 0.86 & -2.99 & & 0.69 & -4.08 & \\
\hline Sudah Menikah & 1.00 & & & 1.00 & & & 1.00 & & \\
\hline $\begin{array}{l}\text { Kedudukan dalam } \\
\text { Rumah Tangga }\end{array}$ & & & $<0.001$ & & & 0.011 & & & 0.006 \\
\hline $\begin{array}{l}\text { Kepala Rumah } \\
\text { Tangga }\end{array}$ & 0.71 & -8.93 & & 1.12 & 2.54 & & 1.23 & 2.75 & \\
\hline $\begin{array}{l}\text { Anggota Rumah } \\
\text { Tangga }\end{array}$ & 1.00 & & & 1.00 & & & 1.00 & & \\
\hline Usia & & & $<0.001$ & & & $<0.001$ & & & \\
\hline $10-19$ & 22.40 & 46.81 & & 3.99 & 14.87 & & - & - & - \\
\hline $20-29$ & 14.77 & 50.71 & & 4.88 & 21.15 & & 1.28 & 2.27 & 0.023 \\
\hline $30-39$ & 5.78 & 37.33 & & 3.38 & 17.74 & & 1.37 & 3.46 & 0.001 \\
\hline $40-49$ & 1.92 & 13.71 & & 1.73 & 7.72 & & - & - & - \\
\hline$>=50$ & 1.00 & & & 1.00 & & & 1.00 & & \\
\hline Pendidikan & & & $<0.001$ & & & $<0.001$ & & & \\
\hline $\begin{array}{l}\text { SD Sederajat ke } \\
\text { bawah }\end{array}$ & 1.00 & & & 1.00 & & & 1.00 & & \\
\hline SMP Sederajat & 2.21 & 23.69 & & 1.74 & 9.71 & & - & - & - \\
\hline SMA Sederajat & 4.82 & 47.06 & & 3.26 & 22.07 & & 2.27 & 8.25 & $<0.001$ \\
\hline Perguruan Tinggi & 13.39 & 39.97 & & 3.61 & 20.14 & & 3.46 & 11.93 & $<0.001$ \\
\hline $\begin{array}{l}\text { Kepemilikan } \\
\text { Ponsel }\end{array}$ & & & $<0.001$ & & & $<0.001$ & & & $<0.001$ \\
\hline $\mathrm{Ya}$ & 18.72 & 61.29 & & 8.92 & 16.64 & & 16.38 & 7.27 & \\
\hline Tidak & 1.00 & & & 1.00 & & & 1.00 & & \\
\hline $\begin{array}{l}\text { Menggunakan } \\
\text { Komputer }\end{array}$ & & & $<0.001$ & & & $<0.001$ & & & $<0.001$ \\
\hline $\mathrm{Ya}$ & 23.96 & 76.63 & & 3.27 & 30.95 & & 6.36 & 24.29 & \\
\hline Tidak & 1.00 & & & 1.00 & & & 1.00 & & \\
\hline Bekerja & & & $<0.001$ & & & $<0.001$ & & & $<0.001$ \\
\hline $\mathrm{Ya}$ & 1.19 & 5.41 & & 1.66 & 12.04 & & 1.87 & 7.86 & \\
\hline Tidak & 1.00 & & & 1.00 & & & 1.00 & & \\
\hline BPJS Non PBI & & & $<0.001$ & & & & & & 0.016 \\
\hline $\mathrm{Ya}$ & 1.32 & 7.68 & & - & - & - & 1.15 & 2.4 & \\
\hline Tidak & 1.00 & & & & & & 1.00 & & \\
\hline Tempat Tinggal & & & $<0.001$ & & & $<0.001$ & & & 0.060 \\
\hline Perkotaan & 1.20 & 6.40 & & 1.30 & 6.24 & & 1.16 & 1.88 & \\
\hline Perdesaan & 1.00 & & & 1.00 & & & 1.00 & & \\
\hline $\begin{array}{l}\text { Pengeluaran Per } \\
\text { kapita (dalam } \\
\text { Jutaan Rupiah) }\end{array}$ & 2.27 & 36.42 & $<0.001$ & 1.88 & 23.95 & $<0.001$ & 2.45 & 20.77 & $<0.001$ \\
\hline
\end{tabular}

Peluang pengguna internet yang memiliki ponsel sebesar 18,72 kali lebih besar dari pada yang tidak memiliki ponsel. Begitu juga untuk e-commerce dan e-banking juga memiliki peluang yang tinggi sebesar 16,64 dan 7,27 kali lebih besar. Individu yang menggunakan komputer memiliki peluang mengadopsi internet, e-commerce, dan $e$ banking sebesar 23,96; 3,27; dan 6,36 kali lebih besar daripada yang tidak menggunakan komputer. Individu yang bekerja juga memiliki peluang yang lebih besar dari pada 
yang tidak bekerja pada ketiga layanan, yaitu 1,19 kali lebih besar untuk internet; 1,66 dan 1,87 kali lebih besar untuk e-commerce dan $e$ banking. Menjadi peserta BPJS non PBI juga berpeluang untuk menggunakan internet dan e-banking sebagai salah satu alat pembayaran tagihan bulanan sebesar 1,32 dan 1,15 kali. Namun dalam hal ini tidak signifikan berpeluang menjadi pengguna e-commerce.

Tinggal di perkotaan juga memiliki peluang lebih besar untuk mengadopsi ketiga layanan yaitu 1,20 untuk internet; 1,30 untuk e-commerce; dan 1,16 untuk e-banking. Penghasilan adalah prediktor yang baik untuk menjelaskan adopsi internet, e-commerce, dan e-banking. Semakin tinggi pengeluaran bulanan, semakin tinggi peluang seseorang mengadopsi ketiga layanan. Ketiga model secara statistik signifikan dan mampu membedakan antara responden yang menggunakan masing-masing layanan dan yang tidak menggunakan.

Model internet dengan benar mengklasifikasikan 88,97 persen kasus yang sesuai, untuk model e-commerce dan $e$ banking masing-masing adalah 94,03 persen dan 98,16 persen. Dari nilai Pseudo R2, variasi pada variabel bebas pada model mampu menjelaskan variasi pada variabel terikat pada model internet sebesar 61,12 persen, e-commerce sebesar 29,46 persen, dan e-banking 34,15 persen. Untuk karakteristik kabupaten digunakan marginal effect. Indeks Gini menunjukkan hasil yang signifikan pada ketiga model. Nilai marginal effect Indeks Gini pada internet sebesar -0,199 menunjukkan bahwa secara rata-rata ketika Indeks Gini naik 1 satuan, maka kemungkinan untuk berbelanja online menurun 19,9 persen. Namun untuk pengguna e-commerce dan e-banking, marginal effect menunjukkan positif dan signifikan. Hal ini menunjukkan bahwa adanya kesenjangan pendapatan antarindividu pada kedua layanan tersebut. Jika IPM naik 1 poin maka kemungkinan individu menjadi pengguna internet meningkat 0,4 persen untuk internet dan 0,02 persen untuk $e$ commerce. Hal ini selaras dengan tingkat pendidikan pengguna kedua layanan tersebut yang menjadi salah satu unsur pembentuk nilai IPM yaitu rata-rata lama sekolah.

Jika persentase kemiskinan naik 1 persen akan menurunkan kemungkinan individu mengadopsi internet sebesar 0,3 persen dan e-commerce sebesar 0,003 persen. Dengan kata lain, meningkatnya pengguna internet dan e-commerce dapat menurunkan angka kemiskinan. Hal ini mengidentifikasikan bahwa dengan mengadopsi kedua layanan tersebut dapat meningkatkan kesejahteraan masyarakat.

Tabel 5

Estimasi Marginal Effect Regresi Logistik untuk Setiap Layanan di Provinsi Jawa Timur 2017

\begin{tabular}{|c|c|c|c|c|c|c|c|c|c|}
\hline \multirow{2}{*}{$\begin{array}{l}\text { Variabel } \\
\text { Karakteristik } \\
\text { Kabupaten }\end{array}$} & \multicolumn{3}{|c|}{ Internet } & \multicolumn{3}{|c|}{ E-commerce } & \multicolumn{3}{|c|}{ E-banking } \\
\hline & $\begin{array}{c}\text { Marginal } \\
\text { effect }\end{array}$ & $\mathrm{z}$ & $\begin{array}{c}p \\
\text { value }\end{array}$ & $\begin{array}{c}\text { Marginal } \\
\text { effect }\end{array}$ & $\mathrm{z}$ & $\begin{array}{c}p \\
\text { value }\end{array}$ & $\begin{array}{c}\text { Marginal } \\
\text { effect }\end{array}$ & $\mathrm{z}$ & $\begin{array}{c}p \\
\text { value }\end{array}$ \\
\hline Indeks Gini & -0.199 & -3.24 & 0.001 & 0.0159 & 2.09 & 0.037 & 0.0055 & 2.60 & 0.009 \\
\hline IPM & 0.004 & 7.25 & $<0.001$ & 0.0002 & 3.44 & 0.001 & - & - & - \\
\hline Persentase Kemiskinan & -0.003 & -4.84 & $<0.001$ & -0.0003 & -3.67 & $<0.001$ & - & - & - \\
\hline Rasio Sinyal Ponsel & 1.197 & 5.43 & $<0.001$ & -0.0592 & -1.68 & 0.092 & - & - & - \\
\hline Jumlah Universitas & -0.001 & -2.76 & 0.006 & -0.0001 & -5.59 & $<0.001$ & 0.000 & 2.42 & 0.015 \\
\hline Constant & 0.00 & -15.89 & $<0.001$ & 0.00 & -4.34 & $<0.001$ & 0.00 & -4.54 & $<0.001$ \\
\hline Jumlah Observasi & 88337 & & & 88337 & & & 88337 & & \\
\hline Wald $X^{2}$ & 68405.57 & Df:21 & & 11694.60 & Df:21 & & 5557.98 & Df:21 & \\
\hline Pseudo $R^{2}$ & 0.6112 & & & 0.2946 & & & 0.3415 & & \\
\hline Correctly Classified & $88.97 \%$ & & & $94.03 \%$ & & & $98.16 \%$ & & \\
\hline
\end{tabular}


$\begin{array}{cccc}\text { Ini } & \text { merupakan } & \text { petunjuk } & \text { bagi } \\ \text { pemerintah } & \text { untuk } & \text { dapat } & \text { terus }\end{array}$ mengembangkan sarana dan prasarana teknologi informasi dan komunikasi agar taraf hidup penduduk semakin meningkat. Sinyal merupakan hal terpenting dalam mengakses internet. Ketika sinyal naik 1 persen maka akan meningkatkan pengguna internet sebesar 119,7 persen. Jumlah universitas menunjukkan hasil yang signifikan namun tidak terlalu berdampak pada ketiga layanan. Hal ini dikarenakan penelitian ini menggunakan jumlah universitas pada setiap kabupaten di Jawa Timur, sehingga tidak dapat memotret secara langsung dampak pada ketiga layanan. Kabupaten yang memiliki banyak universitas belum tentu memiliki banyak mahasiswa dan lulusannya karena ada universitas atau perguruan tinggi yang memiliki murid yang sedikit.

\section{PENUTUP}

\section{Simpulan}

Dengan menggunakan model regresi logistik diperoleh hasil secara empiris yang menunjukkan bahwa odds ratio dan marginal effect pengguna layanan ini dipengaruhi (meskipun dengan intensitas yang berbeda) oleh beberapa variabel. Individu yang memiliki peluang lebih besar untuk menjadi pengguna internet memiliki karakteristik lakilaki, belum menikah, sebagai anggota rumah tangga, berusia $10-19$ tahun. Sedangkan individu yang memiliki peluang lebih besar untuk menjadi pengguna e-commerce dan $e$ banking memiliki karakteristik perempuan, sudah menikah, sebagai kepala rumah tangga, serta berusia 20 - 29 tahun untuk e-commerce dan berusia 30 - 39 tahun untuk e-banking. Individu yang memiliki peluang lebih besar menggunakan ketiga layanan juga memiliki karakteristik lulusan perguruan tinggi, memiliki ponsel, menggunakan komputer, bekerja, pengeluaran perkapita tinggi, serta tinggal di daerah perkotaan.

Kota Malang merupakan kota dengan penduduk yang mengakses internet dan $e$ commerce tertinggi di Jawa Timur, sedangkan e-banking paling banyak diakses di Kota Surabaya. Kabupaten di Pulau Madura masih kurang dalam mengoptimalkan ketiga layanan tersebut. Indeks Gini dan jumlah universitas juga berpengaruh dan signifikan pada ketiga layanan. Begitu juga IPM, persentase kemiskinan dan sinyal berpengaruh dan signifikan pada penggunaan internet dan $e$ commerce. Hasil estimasi tersebut umumnya sangat baik dengan hubungan yang diharapkan, antara odds ratio dan marginal effect, sebagian besar signifikan. Ini sejalan dengan sampel, model, serta teknik estimasi yang memadai.

\section{Saran}

Pemanfaatan media internet akan meningkatkan efektivitas dan efisiensi usaha, baik dari sisi waktu, biaya, maupun tenaga. Dengan begitu, perusahaan dapat mengembangkan usahanya karena perusahaan dapat menjangkau pasar yang lebih luas.

Kegiatan transaksi online ini juga masih banyak menemui kendala dalam hal infrastruktur. Kendala jaringan komunikasi atau koneksi dapat menghambat kegiatan transaksi online.

\section{DAFTAR PUSTAKA}

APJII (2018) Penetrasi \& Perilaku Pengguna Internet Indonesia Survey 2017. Teknopreneur. [Online]. Available from: https://apjii.or.id/survei2017.

Badan Pusat Statistik (2017a) Analisis Hasil Listing Sensus Ekonomi 2016 - Potensi Ekonomi Indonesi. [Online]. Available from:

https://www.bps.go.id/publication/2017/12/ 26/fae6d5d36039ede05d24236f/analisishasil-listing-sensus-ekonomi-2016---potensi-ekonomi-indonesia.html.

Badan Pusat Statistik (2017b) Statistik Kesejahteraan Rakyat 2017. [Online]. Available from: https://www.bps.go.id/publication/2017/12/ 28/5dc3593b43f3d4ac1fb77324/statistikkesejahteraan-rakyat-2017.html.

Badan Pusat Statistik Provinsi Jawa Timur (2017) Jawa Timur Dalam Angka 2017. [Online]. Surabaya, Badan Pusat Statistik. Available from:

https://jatim.bps.go.id/publication/2017/08/ 
11/d618ba11975447a5fffa5f48/provinsijawa-timur-dalam-angka-2017.html.

Daniel, E. (1999) Provision of electronic banking in the UK and the Republic of Ireland. International Journal of Bank Marketing. [Online] 17 (2), 72-83. Available from: doi:10.1108/02652329910258934.

Deaton, A. \& Zaidi, S. (2002) Guidelines for Constructing Consumption Aggregates for Welfare Analysis cb. [Online]. Washington, WorldBank. Available from: https://openknowledge.worldbank.org/hand le/10986/14101.

van Dijk, J. (2012) The evolution of the digital divide: The digital divide turns to inequality of skills and usage. In: Digital enlightenment yearbook. IOS Press Amersterdam. pp. 57-75.

Fonseca, J.R.S. (2014) e-banking culture: A comparison of EU 27 countries and Portuguese case in the EU 27 retail banking context. Journal of Retailing and Consumer Services. [Online] 21 (5), 708-716. Available from: doi:10.1016/j.jretconser.2014.05.006.

Grimes, S. (2000) Rural areas in the information society: diminishing distance or increasing learning capacity? Journal of Rural Studies. [Online] 16 (1), 13-21. Available from: doi:10.1016/S0743-0167(99)00027-3.

Gujarati, D. (2009) Basic Econometrics. 5th edition. New York, McGraw-Hill.

Hilbert, M. (2014) Technological information inequality as an incessantly moving target: The redistribution of information and communication capacities between 1986 and 2010. Journal of the Association for Information Science and Technology. [Online] 65 (4), 821-835. Available from: doi:10.1002/asi.23020.

International Labor Organization (2017) Laporan ketenagakerjaan Indonesia 2017: Memanfaatkan teknologi untuk pertumbuhan dan penciptaan lapangan kerja. [Online]. Available from: https://www.ilo.org/jakarta/whatwedo/publi cations/WCMS_613626/lang-en/index.htm.

Jorgensen, D. (2002) Economic Growth in The Information Age. Cambridge, MIT Press.

Kanbur, R. (2005) Spatial Inequality and Development. Anthony J. Venables (ed.). NewYork, Oxford University Press.

Kiiski, S. \& Pohjola, M. (2002) Cross-country diffusion of the Internet. Information Economics and Policy. [Online] 14 (2),
297-310. Available from: doi:10.1016/S0167-6245(01)00071-3.

Liao, Z. \& Cheung, M.T. (2002) Internet-based ebanking and consumer attitudes: an empirical study. Information \& Management. [Online] 39 (4), 283-295. Available from: doi:10.1016/S03787206(01)00097-0.

Mariscal, J. (2005) Digital divide in a developing country. Telecommunications Policy. [Online] 29 (5-6), 409-428. Available from: doi:10.1016/j.telpol.2005.03.004.

Martín, S.S. \& Jiménez, N.H. (2011) Online buying perceptions in Spain: Can gender make a difference? Electronic Markets. [Online] 21 (4), 267-281. Available from: doi:10.1007/s12525-011-0074-y.

Mossberger, K., Tolbert, C.J. \& Stansbury, M. (2003) Virtual inequality: Beyond the digital divide. Washington, Georgetown University Press.

Nor, K. (2013) Adoption of Internet Banking by Yemeni Consumers: An Empirical Investigation. Australian Journal of Basic and Applied Sciences. 7 (2), 182-189.

Norris, P. (2001) Digital divide: civic engagement, information poverty, and the Internet world wide. NewYork, Cambridge University Press.

Otoritas Jasa Keuangan (2017) Laporan Keuangan 2016. [Online]. Available from: https://www.ojk.go.id/id/data-danstatistik/laporan-tahunan/Pages/LaporanKeuangan-OJK-Tahun-2016-Audit.aspx.

Quibria, M.., Ahmed, S.N., Tschang, T. \& ReyesMacasaquit, M.-L. (2003) Digital divide: determinants and policies with special reference to Asia. Journal of Asian Economics. [Online] 13 (6), 811-825. Available from: doi:10.1016/S10490078(02)00186-0.

Rallet, A., \& Rochelandet, F. (2007) ICTs and inequalities: the digital divide. New York, Cambridge University Press.

Rao, P. \& Holt, D. (2005) Do green supply chains lead to competitiveness and economic performance? International Journal of Operations \& Production Management. [Online] 25 (9), 898-916. Available from: doi:10.1108/01443570510613956.

Richard, M.-O., Chebat, J.-C., Yang, Z. \& Putrevu, S. (2010) A proposed model of online consumer behavior: Assessing the role of gender. Journal of Business Research. [Online] 63 (9-10), 926-934. Available from: doi:10.1016/j.jbusres.2009.02.027. 
Serener, B. (2016) Statistical Analysis of Internet Banking Usage with Logistic Regression. Procedia Computer Science. [Online] 102 (August), 648-653. Available from: doi:10.1016/j.procs.2016.09.456.

Turban, E. (2002) Electronic Commerce. New Jersey, Pearson Prentice Hall.

Warschauer, M. (2003) Technology and social inclusion: rethinking the digital divide. Cambridge, MIT Press.
Widagdo, P.B. (2016) Perkembangan Electronic Commerce (E-Commerce) di Indonesia. [Online]. (December). Available from: https://www.academia.edu/30456465/Perke mbangan_Electronic_Commerce_ECommerce di_Indonesia.

Wilson, K.R., Wallin, J.S. \& Reiser, C. (2003) Social Stratification and the Digital Divide. Social Science Computer Review. [Online] 21 (2), 133-143. Available from: doi:10.1177/0894439303021002001. 